\title{
Increasing or Widening Participation in Higher Education? - a European overview
}

\author{
MICHAEL OSBORNE
}

\section{Introduction}

In the latter decades of the $20^{\text {th }}$ century we have seen a major expansion of the higher education (HE) system in Europe. From a small élite sector where some $5 \%$ of school-leavers participate - mostly immediately after leaving the compulsory sector - , there now exists a greatly expanded mass and in some cases universal system. ${ }^{1}$ According to recent OECD (2001a, p. 148) statistics for 22 of its member countries (of which 16 are European), on average, four out of ten school leavers are likely to participate in higher Tertiary A education ${ }^{2}$ in the course of their lives. In some countries, this proportion rises to one in two, and in Finland, New Zealand and Sweden to at least two out of three entering this form of higher education. Between 1995 and 1999, OECD reports that, with the exception of three countries under study, all showed increases in participation in higher education, the average increase being $15 \%$, with some nations showing rises of up to $84 \%$ (Poland) during this period. Whilst these increases to a certain extent are a reflection of changing demography, only in a minority of countries (Ireland, Mexico and Poland) does increasing population size account for significant change. Even then, as in all nations, actual increases in participation rate account for significantly more of the overall change.

These figures, of course, reflect significant differences between societies that most obviously relate to the duration of higher Tertiary level A education which varies from 3 years (e.g. English and Irish Bachelor's degrees) to five years or more (e.g. the Italian Laurea). Furthermore, age of initial participation varies significantly, and, in a number of countries, entry to HE is delayed to well beyond school-leaving age, reflecting in some societies the value ascribed to prior work experience, in others the structural forms that facilitate later participation and measures that have been specifically developed to widen the constituency that $\mathrm{HE}$ serves.

Gellert (1993, p. 17) almost a decade ago wrote that there are a number of 'essential areas of change' in HE systems. A number of these features are closely linked to the expansions that have occurred from the 1960s onwards and which, particularly in Central and Eastern Europe, continue today. Amongst the trends that Gellert identified were institutional differentiation, which includes the establishment of new forms of higher education institutions and programmes, functional modification, new modes of teaching and learning, increased concern with access and educational opportunity, the greater prevalence of government 
intervention and accountability, and the greater influence of the European Union. These trends combine both the developing features of systems and some of the factors that have influenced these developments and form one of a number of useful frameworks for the analysis of recent trends in participation.

The thrust to increase and, to a lesser or greater degree, to widen participation in higher education in most European societies is associated with a number of themes within the larger banner of lifelong learning. They include 'the economic imperatives created by global competition, technological change and the challenge of the knowledge economy, individual responsibility and self-improvement, employability, flexibility of institutions and individuals, social inclusion and citizenship' (Osborne, 2003). There have been worldwide concerns expressed by both international bodies and national governments that there are strong economic reasons for increasing access and for widening the constituency that higher education serves by including those groups who have traditionally been excluded. These strands of thought are evident in key statements of many international organisations such as the European Commission (1995; 2001a; 2001b) (as detailed by Pat Davies in this issue), the Council of Europe (1996; 1999; 2001), UNESCO (1998a; 1998b), OECD (2001), the International Labour Office (ILO) (2000) and many others.

The drive towards equity and social cohesion is certainly a clear political goal at European level. For instance, the Budapest Declaration of the Council of Europe has called for:

a new strategy for social cohesion promoting a more tolerant and just European society based on solidarity, shared values and a common cultural heritage; education for democratic citizenship as a lifelong experience fostering active participation of Europeans in all spheres of life; extensive use of information and communication technologies maximising their educational potential (Rougaas, 2001, p. 10).

This reaffirms previous Council of Europe statements that emphasise equality of opportunity irrespective of political, religious, socio-economic, and cultural background (Council of Europe, 1996). Similar sentiments are found in European Commission documents, from its White Paper on Lifelong Learning (European Commission, 1995) through to its recent Memorandum on Lifelong Learning (MLL) (European Commission, 2001a) and the proposal for setting up a European Area of Lifelong Learning (European Commission, 2001b). Michel Jouve (2001, p. 62) has recently spoken of 'the need to render traditional education systems more accessible and less rigid so that learners of all ages can embark on reasonably individual study programmes' when formulating strategies for lifelong learning within the EC. The emphasis in this sentiment, of course, is that the supply of education and training should be led by the demand and needs of learners and society rather than by traditional patterns of organisational supply. The Swedish response to the MLL crystallises this perspective by expressing its concern about an 'educational dead-end' and speaks about a 'far reaching change from a supply steered system to a flexible system steered by changing individual demands'. The response continues: 'university studies cannot be opened to new and larger groups if the universities and university colleges themselves do not change' (Ministry of Education and Science, 2001, p. 19). 
The thrust of EC policy in lifelong learning has been criticised for being overduly instrumental and driven by economic considerations, putting greatest emphasis on meeting skills shortages, labour market outcomes and the role of the formal sector. It is, however, quite clear that, as policy has developed over the years, it has been realised that the goals of economic development could not be achieved without concomitant social developments to combat exclusion. Increased access to education therefore is seen as one means of ensuring that those most at risk for reasons including geographical location, socio-economic situation, ethnicity and disability are afforded greater opportunity within the 'knowledge society'. The development of EC policy in this respect is analysed by P. Davies in this issue. The economic and social strands of widening participation are often represented as dichotomous, like many conceptual strands in education, but, of course, are representative of closely linked objectives. The goal of securing increased and wider access to education is one means of fulfilling hopes and aspirations, in so doing providing an 'essential safety valve of social mobility' at a time when economic divides are becoming greater (Council of Europe, 1996, p. 9).

\section{Structural Differentiation and Access}

At a European level, there have been major structural changes within higher education in the Member States of the European Union, its candidate countries and beyond as increased convergence and harmonisation are sought that could hardly have been envisaged little more than a decade ago.

At one pole, at a system level it is possible to identify countries where there are a well-integrated unified higher education system and highly equitable procedures for ensuring access irrespective of personal background. For instance, in Sweden since reforms in 1977, when a number of new higher education colleges were set up in all regions of the country and national university aptitude tests were introduced to increase the prospects for entry of adults over the age of 25 and with 4 years' work experience, there has been widespread access to HE. Whilst the system is not completely open in the sense that it does operate certain forms of selection through limitations at programme and subject level (numerus clausus), it is one in which 'the idea of lifelong learning has become a reality not only to politicians but, most of all, to Swedes themselves' (Bron \& Agelii, 2000, p. 98). Most countries, by contrast, present much less integrated provision.

In many countries, institutional differentiation is evident in the creation of new types of institutions that both parallel and complement existing universities. In certain cases, such as the UK, in an initial phase of development, a polytechnic sector was created as a parallel vocational and technical alternative to universities and became responsible for much of the widening of participation in HE from the 1960 s onwards. The ending of this binary line, when these institutions were afforded the status of universities, was in itself a policy development to combat perceived obstacles to increasing participation by the then Conservative government (Department of Education and Science, 1991). The subsequent focus from the 1990s until the present time on situating increasing HE provision in Further Education Colleges (FECs) in Scotland, and to a lesser extent in England and Wales, has been based on its accessibility to students in terms of geographical locality, educational ethos, and the relatively lower cost to government. The use of these institutions both as providers of qualifications with national recognition 
and as feeders to the second or third year of universities has effectively established a new, but fuzzy, binary line, and a higher education structure that increasingly is assuming the characteristic of a stratified system. ${ }^{3}$ Hence, the UK system is beginning to resemble that of North America with its two-year Community College programmes that are designed to articulate to universities (Bonham, 2002; Burtch, 2002). In certain UK institutions the links between HEIs and FECs have in recent years led to complete amalgamations and the creation of dual sector post-16 institutions similar to those established in some Australian States (Wheelahan, 2002). Fairly similar systems exist in other European States. For instance, in the Netherlands, higher professional education ( $\mathrm{HBO}$ - Hoger Beroeps Onderwijs) at hogescholen has expanded considerably since the 1970s and it is possible to enter university study (Wetenschappelijk Onderwijs) with the HBO propaedeutic (i.e. first year of higher education) certificate.

However, in many European countries, there exist two more distinct parallel sectors $^{4}$ of higher level provision within a dual or binary system and a set of tertiary establishments outside the university sector that is largely unconnected to these. Most well-known is the German system of both universities and Fachhochschulen (sometimes translated as 'Universities of Applied Sciences'). The latter were introduced in 1970-71 and are characterised by shorter 3- or 4-year programmes, a practice-oriented bias, an integrated semester or two of work experience, and lecturers who have, in addition to their academic qualifications, gained professional experience outside the field of higher education. It is the establishment of the Fachhochschulen, which provide access for those without the traditional school-leaving qualification, the Abitur, together with the expansion of academictrack upper school education leading to the Abitur that have led to the massification of the German HE system (Wolter, 2000). A binary line exists in a number of other countries. In some nations, this has involved the creation of new HE forms in very recent times, such as the polytechnics (ammattikorkeakoulu) established in 1992 in Finland. In Finland, as elsewhere, the creation of a new form of HE has involved rebranding and upgrading vocational provision in the coming together of a number of diverse institutions under one banner. This has also been the case with the establishment of the Institutes of Technology in Ireland. These forms, as is the case with the previously described systems with strongly vocational orientations, have been developed with specific labour market objectives, though this is not necessarily the outcome in practice. So for instance, the function of the ammattikorkeakoulu was to be practical occupational schooling, while the universities would offer a more widely applicable theoretical basis for professional careers. However, Nurmi (1998) sees the development of the polytechnics as a structural response to a social demand rather than to an economic need for more graduates. Although created with a vocational orientation, Nurmi suggests that the ammattikorkeakoulu suffer from a lack of practical orientation and from academic drift. It is the resultant creation of surplus graduates that makes institutional differentiation necessary.

It is now increasingly evident that, as the higher education systems of Central and Eastern Europe are seeking to transform, they too are looking to increase participation through the creation of new forms of $\mathrm{HE}$ structures. For instance, Marga (2002, p. 133) reports that short-cycle higher education had been disregarded in the post-World War II period in Romania and the creation since 1998 of a national network of university colleges in over 50 cities is a structural response to this 
position. Cerych (2002, p. 112) reports that the 'German Fachhochschule, the Dutch $\mathrm{HBO}$ or the OECD concept of 'short-cycle' or 'non-university' sector higher education ... have certainly inspired reforms in Czech education'. Hence, Higher Professional Schools (Vyssi odborna skola) based on the HBO have been set up in the Czech Republic. This tendency is, of course, accelerated by the desire of the majority of countries in this region in Europe to harmonise with those of the Western countries within the framework of the Bologna agreement. ${ }^{5}$ In the Czech Republic, like in many countries in which educational structures have been transformed, Bachelor's degrees along the lines of Anglo-Saxon models are being established.

Given this move to greater institutional differentiation, what difference has this really made to increasing the opportunities of traditionally excluded groups in higher education? Using the statistical indicators of organisations such as OECD, it is difficult to gather data across a range of socio-demographic indicators that would indicate the extent to which participation has been widened as against merely increased. However, a number of commentators (Schuetze \& Slowey, 2000; Murphy et al., 2002) have reported that the quantitative expansion of higher education has not necessarily been accompanied by a system-wide improvement in access for those groups in society who have historically not participated. Examples from two quite diverse countries provide evidence for such assertions. In the UK, where widening access as an aim of government is heavily embedded in policy and practice, there is still considerable skewing of participation by social class and clear evidence that it is those more recently established universities and non-university $\mathrm{HE}$ that accommodate most readily the 'non-traditional' students. In Spain, reforms in the university curricula in 1989 were introduced to both update their content and provide greater flexibility within the system. They brought about the expansion of 3-year short cycle programmes, creating greater possibilities of access for young people from lower socio-economic groups (San Segundo, 2002). Even so, recent analyses would suggest that inequality of opportunity by socio-economic status still remains a major problem (Albert, 2000; Petrongolo \& San Segundo, 2002).

\section{Functional Modification}

Gellert (1993, p. 17) refers to a range of functional modifications for higher education as new tasks and purpose emerge. Broadly, he has identified three strands: the Humboldtian model concentrating on research, as exemplified historically in Germany; the professional model of the French Grandes Ecoles; and the English model of 'personality development'. None of these is completely immune from the policy objectives of increasing and widening access. It is quite clear that, irrespective of historical traditions, those aspects of the functions of most types of institutions have changed in the light of the political pressures to admit a more diverse student body.

There are huge caveats here inasmuch as the almost universal commitment to the social justice agenda implicit within lifelong learning that is headlined in mission statements and prospectuses of institutions, in reality, can reflect very different practices on the ground (Davies, 1996) and is an arena for considerable conflict. For instance, in an analysis of the behaviour of two universities - one in the UK and one in Belgium - in relation to access and participation, Bourgeois 
et al. (1999, p. 41) identify four areas of conflict. Firstly, there are multiple and ambiguous roles and missions for the university in a society 'that increases its demands, expectations and pressure upon it'. Secondly, there is discord between the 'social necessity of those missions and the need to achieve the 'system' goals of survival, competitiveness and growth'. Thirdly, there is conflict amongst the academics who do not form a 'single professional body'; and fourthly between the professionals, and administration and management.

Furthermore, it is very difficult, as Gellert (1993, p. 238) suggests, to label a particular society as belonging to a particular paradigm, since each national model will inevitably consist of a number of functional elements.

\section{The Forms of Responses at Governmental Level - Institutions and Individuals}

Despite this difficulty, it is nonetheless possible to identify measures that have been taken as part of national strategic planning in most societies from the $1970 \mathrm{~s}$ onwards, and these have left few institutions immune from the drive to increase and widen participation. They range from a set of supply-side schemes through to initiatives that seek to stimulate new demand. In some societies, the measures take the form of 'carrots and sticks' with types of incentivisation at institutional level to meet particular targets and penalties (normally financial) for not doing so. Typical of this approach are the financial mechanisms that have been put in place within each of the component countries of the UK, and have taken the form of both grants to develop initiatives and core funding linked to achieving targets of students, particularly those from geographical areas with poor participation statistics (Thomas, 2002, pp. 29-48; Murphy et al., 2002). In other societies, prescription of particular practices is laid down within legal requirements, though the extent to which such directives impact on participation will be variable. In Ireland, for instance, the Universities Act of 1997 imposes a duty on 'universities to prepare and implement statements of their policies in respect of . . access to the university and to university education by economically or socially disadvantaged people, by people who have a disability and by people from sections of society significantly under represented in the student body...' (Thornhill, 2002, p. 53). In France, there are laws and complementary decrees with respect to access to higher education that mandate the implementation of mechanisms to allow entry by those without traditional school-leaving qualifications, and most radically through systematic use of accreditation of prior experiential learning (Jallade, 2000). Known originally as La Validation des Acquis Professionnels (VAP), following legislation in 2002, the process is now termed Validation d'Acquis de l'Expérience (VAE). Gallacher and Feutrie describe this system in some detail in this issue.

As a result, many of the most élite institutions and some of the most restrictive professional fields exercise some form of activity in the widening participation arena. For instance, in the UK, many ancient universities arrange Summer Schools for pupils from state schools and areas of educational disadvantage as a 'second chance' to demonstrate their potential for entry. In France, new VAE legislation in the area of the accreditation of prior experiential learning now brings all institutions, including the Grandes Ecoles, into a system that provides both the opportunity for access and for credit towards a degree or for a whole degree, based on the validation of learning acquired outside the academy. Thus, these measures 
encourage institutions (with greater or lesser degrees of coercion) to remove the barriers that they and governments themselves have created.

Of course, incentives at organisational level may not be sufficient if unaccompanied by support for participation that impacts directly on individuals themselves. However, we see quite different forms of response in the direct support of students across Europe. The literature on participation and non-participation in education is vast and constitutes a major field of academic study that is well beyond the remit of this article. ${ }^{6}$ In addition to institutional barriers there exist situational factors that relate to the ways in which people's life histories are affected by their social context and barriers revolving around their personal and psychological characteristics, such as levels of self-esteem and academic ability. As Williams (1997) has suggested, the sets of factors, intrinsic to these forms of barriers, interact and impact on individual decision-making in different ways, depending on individual backgrounds and circumstances and different factors have salience at different times. Whilst the barriers created by institutions are combated by a range of measures that stems from governments and institutions themselves, the stimulation of demand, particularly new demand, is unlikely to occur without addressing the particular situations of individuals. Davies et al. (2002) have mapped situational factors in the context of mature student decisionmaking that include financial circumstances and attitudes to debt; educational background, experience and qualifications; domestic situation and location; occupational status; perceptions of labour market opportunities and value of $\mathrm{HE}$ qualifications; career aspirations; and support (if any) from employers. Clearly, financial issues, both current and prospective, are high on the list of perceived barriers to participation and here we see mixed messages across Europe from governments.

In many Nordic countries there is strong financial support for access to higher education for adults with work experience. For instance, in Denmark, further education at an advanced level is organised to be compatible with work and support for full-time advanced education at a higher level is provided by the State in the case of those over 25 (Jensen \& Hauch, 2003). By contrast, in some other societies, modest and often inadequate funding in the form of grants and loans is made available to support individuals, and in many States, students must make at least some personal contribution to fees. Thus, as HE systems have massified, many governments have moved more of the burden of cost to students, reflecting a view that participation is an individual endeavour with personal economic gains, as well as a state investment. As a palliative, some of the perceived negative effects of marketisation of $\mathrm{HE}$ may at the same time be ameliorated through a variety of support measures. Referring to UK policy, Naidoo (2000) describes widening participation in terms of 'third way' politics, 'mid-way between state collectivism and unregulated market economy', a useful metaphor in this context. The sense of balance implicit within this concept is, however, a dynamic one and it is evident that a number of financial measures has increased the burden on students and discouraged participation, particularly by mature students (Davies et al., 2002). There exists what appears at times like a policy seesaw, with financial corrections introduced as a response to what Morgan-Klein (2000) describes as 'welfarist concerns'. These considerations have recently again become prominent in the UK where it has become clear that targets of $50 \%$ participation of young people in $\mathrm{HE}$ are going to be difficult to achieve. Thus, in July 2002, a proposal for an 
'education maintenance allowance' for young, full-time students from low-income families was announced in the recognition that stronger incentives for participation would be necessary.

At one extreme, in some societies the costs of some forms of higher education are fixed at whatever levels the market can bear. With the burgeoning numbers of private institutions emerging in a number of Central and Eastern Europe countries, with Poland a notable example, it may be that this tendency will increase, although mediated by a system of loans. ${ }^{7}$

No analysis of widening participation therefore can ignore the balances of costs and benefits, actual and as perceived by potential students. Clearly, across Europe there are still societies where the up-front cost is a deterrent to participation, irrespective of the evidence of prospective benefit.

\section{The Forms of Response at Organisational Level}

Because of the proliferation and diversity of provision, it is difficult to provide a complete overview of the forms that responses within the field of widening participation are taking in Europe. To an extent, this difficulty is a function of how to classify the purposes of activities and how sensibly boundaries can be drawn around the various forms that initiatives take.

Certain forms of activity do provide access to the higher education curriculum, but have not expressly been designed as a direct route to higher education qualifications. These include certain programmes directed towards adults, some forms of 'awareness raising' and the fundamental re-structuring of both school and vocational curricula.

The indirect approach towards adults is perhaps exemplified by the extramural tradition in the UK and its more recent manifestation in an accredited form. These short courses provide completely open access and offer opportunities for those who have an interest in academic knowledge to experience $a$ higher education curriculum. ${ }^{8}$ However, their purpose is not directly related to facilitating access to mainstream HE qualifications. Nonetheless, there is evidence from Ireland which suggests that extra-mural provision can act as an informal 'first step' for many mature students, either by allowing them to 'test' the waters in $\mathrm{HE}$ or increasing their interest in progression (Inglis \& Murphy, 1999).

Other interventions are even less direct, as, for instance, is the case with parent education in Spain. Although participation amongst school-leavers in higher education in Spain is relatively high by OECD standards, as in many other countries it relates closely to socio-economic position, with working class pupils disproportionately represented. Initiatives such as parent education (las escuelas de padres) indicate that these may be mechanisms that produce through a cascade effect greater participation amongst these groups (Cases \& Lopez, 1996), breaking down the inter-generational inheritance of inequitable access to or participation in higher level education. This form of intervention is a reflection of a perception that there is arguably greater efficiency in targeting resources towards measures during early years of schooling that pre-empt poor levels of progression to $\mathrm{HE}$ rather than in remediating its effects in later years. Hence, several schemes described later increasingly focus on awareness raising during the compulsory school years. The role of schools in this respect is covered in this issue by David Istance. 
Simply raising aspirations in the high school years may not be enough unless accompanied by fundamental changes in both academic and vocational pathways in terms of structure, form, content and teaching and learning approaches. In the Netherlands, a revision of the structure of secondary vocational education within a competence-based framework represents one example of a perspective that the foundations for lifelong learning are laid down by the acquisition of a set of core competences. ${ }^{9}$ Dutch thinking also gives prominence to the potential of new teaching and learning approaches. The attention given to the constructivist paradigm highlights the importance of meaning, reflection and context, aspects of learning that may be readily built upon in later years. In Scotland, the restructuring of the later years of secondary education in the Higher Still reform has seen a coming together of previously separated 'academic' and 'vocational' routes (Scottish Office, 1998). The aim in part is to create a greater staying-on rate beyond 16 and new systems of assessment that allow a larger proportion of young people to obtain qualifications and thereby progress to tertiary education.

In terms of how best to conceptualise and categorise initiatives that have been designed with the direct purpose of widening participation in order to make them more amenable to further analysis, a recent report from Universities Scotland (2001) on access in Scottish HEIs is useful. Institutional developments are described in terms of how they address three issues affecting access and retention: academic (raising entry qualifications); cultural (raising awareness); and internal (changing institutional structures). Three examples from Scotland show quite clearly ways in which these issues are being tackled with respect to young people. Summer Schools at universities for school pupils from geographical areas with histories of educational disadvantage are viewed as a means of addressing the academic issue of raising students' qualifications prior to entry. Compacts between schools and universities within which structured arrangements for interchanges are planned for pupils from their early years in secondary education are seen as strategies to create the perception that $\mathrm{HE}$ is a possible route for individuals for whom this had either not seemed feasible or had not been considered. The aforementioned Higher Still scheme and the pressure currently being exerted for all institutions offering $\mathrm{HE}$ to respect the credit tariffs of the Scottish Credit Accumulation and Transfer Scheme (SCOTCATS) (Scottish Parliament, 2002) are likely to lead to further organisational change to accommodate these frameworks.

Another distinction provided by Toyne (1990, pp. 63-65) is also helpful. He has categorised two broad types of access initiative - initiatives that focus on people 'getting in' to $\mathrm{HE}$ and access initiatives that lay emphasis on the staff of universities 'getting out' of the campus into the community to reach people who are underrepresented in HE. In a recent study on widening participation, these two types have been defined as in-reach and out-reach respectively (Murphy et al., 2002) and in this issue of the Journal Mark Murphy and Ted Fleming present cases of out-reach schemes. A number of initiatives, however, can neither be categorised primarily as in- or out-reach, and have more to do with transformations and adjustments to the structure, administration and delivery of HE programmes. They are broadly referred to in the same study as flexible access initiatives and correspond to the aforementioned internal developments. This three-part map of access is illustrated in Figure 1.

The category of forms described as in-reach refers to those actions of higher education associated with improving supply by creating new ways for students to 


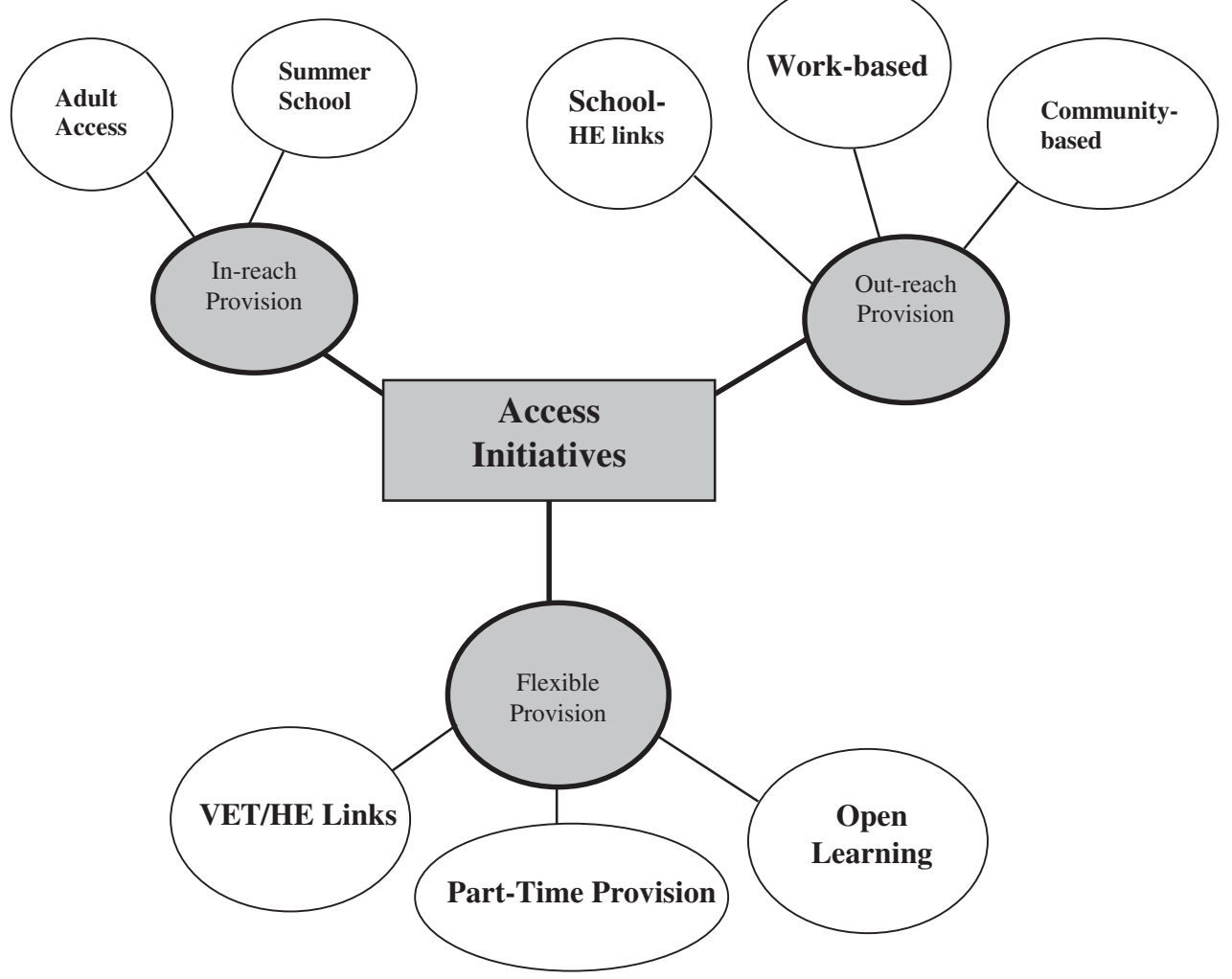

FIGURE 1. A Map of Access Initiatives (Murphy et al. 2002)

access existing provision. These include alternative entry tests for adults, customised courses and other procedures that allow a second opportunity to demonstrate potential and are often accompanied by relaxation of entry requirements. The degree to which these arrangements represent radical departures from standard practices and a real commitment to openness is quite variable. For example, in France, there have existed since 1969 mechanisms such as the Special University Entrance Examination (Examen Spécial d'Entrée à l'Université (ESEU)), and later the Diplome d'Accès aux Etudes Universitaires (DAEU), introduced for adults who did not complete the Baccalauréat at school (Feutrie, 1996; Davies, 1999). Such systems are also a feature of the Spanish system with its Prueba de acceso a la universidad para mayores de 25 años (Ortega \& Camara, 2001). All of the Spanish Autonomous Legislative Assemblies have charged their respective Adult Education Systems with the training of adults over 25 years of age who want to prepare for these examinations for university entrance, the LOGSE (Ley Orgánica General del Sistema Educativo) (article 53) having established the possibility of such access for adults in 1990. No specific qualification is required for this examination which is equivalent to the standard entry qualification to $\mathrm{HE}$ taken by school age entrants. Although many thousands of students in Spain have achieved access through this route and many state and private centres of adult 
education have been set up to provide preparatory programmes for the examination, many more have failed it (Osborne, 1995). This form of 'second chance' is largely a replication of the traditional school-leaving examinations, is culturally specific (Bourgeois \& Frenay, 2001) and has not been attuned to the needs of adult aspirants. Other countries focus less upon a demonstration of a body of knowledge, but more on tests of aptitude, as is the case in Sweden through municipal adult education (Komvux) or Folk High Schools (Bron \& Agélii, 2000). The potential merits of selection using indicators other than academic knowledge as traditionally construed have also entered debates around entry to élite professions. In the UK, public discussions about entry to medicine have led to the consideration of supplementing traditional academic grades with a range of psychometric tests based on Australian models as selection criteria (Powis \& Bristow, 1997; Rolfe \& Powis, 1997). These include the assessment of problem solving skills, moral and ethical reasoning as well as personality characteristics, such as empathy, self-confidence, aloofness and narcissism.

Widening participation in the out-reach mode is concerned with collaboration and partnership. Emerging university partnerships with schools, communities and employers refer to those schemes whereby HEIs actively engage with underrepresented groups and the socially excluded outside their own boundaries. The primary objective of such out-reach initiatives is to target individuals who believe $\mathrm{HE}$ is 'not for them'. Hence, a strong element in out-reach is the attempt to counter dispositional barriers by creating greater awareness of what might be possible and thereby stimulating new demand.

The forms that such collaborations take are multi-faceted and have been described and analysed in an international context in a number of recent publications (Thomas et al., 2002; Woodrow, 2002; Murphy et al., 2002; Osborne, 2003). Woodrow and Thomas (2002) present a four-fold typology of collaboration based on studies from Australia, Ireland, the Netherlands and the US in which they describe the vertical, longitudinal, all-embracing and integrated versions. The vertical model refers to strategies that better facilitate direct entry from a particular sector to $\mathrm{HE}$, as is exemplified in the links between Further Education Colleges and universities in the UK (Morgan-Klein \& Murphy, 2002) and various models of workplace learning (Brennan \& Little, 1996). The longitudinal model does not sharply focus solely on $\mathrm{HE}$ as an outcome, but seeks 'to achieve for its target group a continuum of cross-sector learning opportunities stretching from primary education into employment' (Woodrow \& Thomas, 2002, p. 13). Eggink (2002) describes a regional strategy of this form in the Netherlands to tackle the low participation rates of minority groups that is based on cooperation between three sectors around Utrecht. Here the Regional Opleidengen Centrum Utrecht, the Hogeschool van Utrecht and the Universiteit van Utrecht have created what is described as the 'Utrecht Bridge' to improve the educational infrastructure. Woodrow and Thomas' all-embracing model, exemplified by Bermingham's (2002) case study from Cork in Ireland, describes a regional strategy that encompasses multiple players and many dimensions from primary schools through to universities. It is distinguished from previous models not only by the breadth of partnership, but also by the extent of the involvement of all stakeholders, including those seeking access in the process itself, and by seeking to change the nature of supply. Integration refers to those models where institutional barriers 
have (at least ostensibly) been dissolved, and most obviously these are evident in those countries where Vocational Education and Training (VET) colleges and universities have been integrated to form a common post-16 dual-mode system (Wheelahan, 2002). There are obvious advantages to such strategies, since much evidence points to substantial barriers existing at points of institutional transition.

Flexible arrangements are not completely distinguishable from out-reach activity as is evident in links between VET and universities. Flexibility implies significant structural modification in systems, which may or may not be accompanied by collaboration, although in many cases it is a facilitating mechanism. Flexibility in the context of widening participation refers to both spatial and temporal matters, namely changes that allow students' access to education in locations and modes and at times that to at least a certain degree are of individuals' rather than institutions' choosing. It also refers to those mechanisms that challenge constructions of what constitutes knowledge at higher education level and the means by which knowledge can be acquired and demonstrated. This is the focus of Brenda Morgan-Klein's article in this issue.

The move to modular forms of higher education in many countries in which distinct elements of credit can be accumulated both horizontally at a given level and vertically through levels provides an obvious form that flexibility takes. Increasingly there is a tendency that degrees may be constructed more readily in part-time mode, in workplaces and other off-campus locations and through distance education, often using new forms of digital technologies. In some cases, schemes may consist of a multiplicity of these elements.

However, as Trow (1999, p. 315) comments when comparing US and European universities, the latter 'move slowly towards modular courses and the accumulation of course credits, and even more slowly to credit transfer'. Nonetheless, credit accumulation and transfer schemes are becoming more commonplace across Europe and form a template for much of institutional flexibility (e.g. Lithuania (Targamadz et al., 2000) and Norway (Moe, 2003) to name but two). Tendencies in this direction are clearly being driven through the Bologna Declaration of 1999, which seeks, inter alia, the development of a credit system to improve student mobility within the framework of the European Credit and Transfer System (ECTS), as Pat Davies reports in this issue.

The creation of distance education universities as a means of combating lack of educational opportunity for reasons of geographical location, disability (CEDEFOP, 2001), and employment and home circumstances has a long history. Numerous examples exist of this form of provision being used as a strategy for securing 'second chances'. They include the Universitat Oberta de Catalunya in Spain (Sangra, 2001), the Dutch Open University (Dijkstra, 2001) and the Finnish Open University structure described by Tuomi and Parjanen in this issue. Certain forms of accreditation of prior experiential learning (APEL) and work-based learning such as La Validation D'Acquis de l'Expérience (VAE) in France present fundamental challenges to the structure of traditional higher education qualifications such as the diplome (Davies, 1999). However, as Feutrie and Gallacher argue in this issue, APEL schemes have largely failed in their assault on traditional structures and there have been many disappointments in the success of work-based schemes, with considerable lack of commitment from companies. 


\section{Conclusion}

In an earlier article, we argued that the purposes of initiatives to widen participation were associated with economic instrumentalism, social justice, and pragmatism and expediency (Gallacher et al., 1996). Little has changed in intervening years with respect to these objectives, though the extent, scope and forms of widening participation policy and practice have diversified considerably. The three themes can still be clearly identified within the wide European domain. To a greater or lesser degree massification is economically-driven; struggles for social justice have intentionally led to certain gains for historically excluded groups, though the resultant changes in HE practice are differentially distributed according to institutional history, tradition and form. Much change is undoubtedly pragmatic and, rather than a response to genuine commitment to provide greater equity, is a short-term response to decreases in demand from traditional entrants. Much done in the name of widening participation by institutions is probably a necessity to meet growing quantitative targets and in extremis to secure institutional survival in the light of falling birth rates. The resultant shifts in profile are inevitable rather than planned.

It is therefore of particular interest to examine the extent to which certain routes represent a real widening of opportunity in terms of both progression to further higher education and the labour market as against an educational deadend. Halsey (1992) perspicaciously predicted that, despite the widening of participation, the relative gains of the under-represented might be limited, as élite institutions preserve their traditional boundaries. There may be merits, but also dangers that, in many HE systems, whether they be dual, binary, stratified or unified, one part of the system only takes on the bulk of the widening participation remit. Progression routes to other arms of these systems and to certain parts of the labour market may as a consequence be limited. An alternative argument, however, is that certain forms of offer, particularly short-cycle vocational HE, perhaps combined with employment, present the most viable option for many traditionally non-participants. For instance, for mature entrants whose labour market opportunities are likely to be relatively poor even after tertiary level A study, and whose lifelong economic position may have worsened as a result of the costs of study (OECD 2001b), the choice of a Hogescholen, Fachhochschule or FE College may be an exceedingly rational choice and indeed in labour market terms very successful.

However, as yet, there is little information on the relative success of different mixes of institutional models in different nations. In some countries such as Denmark and the Flemish Community of Belgium, relatively high numbers of individuals enter shorter cycle tertiary level $\mathrm{B}$ higher education, thereby providing a counter-balance to the low level of entry into tertiary level A higher education. It may very well be the case that this is a sensible balance for the State in terms of both input and outcome.

When assessing the forms that provision to widen access takes, it is clear that, to at least a certain extent, there are emerging changing relationships between supply of and demand for education. There has been a shift in the policy agenda surrounding widening participation and social inclusion from a focus on institutional and financial disincentives to participation to more cultural and dispositional barriers. Interventions are considerably more pro-active now than in earlier 
periods of university expansion when policy levers largely took the form of supplying more of the same type of provision. Then only at the edges did a few politicised zealots at institutional and local level create alternative schemes largely targeted at adult entry. There have been many shifts in the last decade in terms of institutional responses, forms of collaboration, target groups and locations of learning. Now we see a spectrum of forms of activity involving multi-institutional collaboration across sectors, on and off campus and in digital form, and interventions at all ages in the life cycle with clear moves towards the younger socially excluded (Bourgeois \& Merril, 2001).

However, there still remain a number of questions around the intentions and effectiveness of these interventions. Improving access is one thing, but ensuring progression both within and beyond higher education is another. It is clear that many more people in Europe now benefit from increased and wider participation. However, the gains may not be as widespread as the champions of access would wish, and equity in terms of entry to higher education is differentially spread across Europe within the panoply of institutions offering $\mathrm{HE}$ and within discipline areas. As Bourgeois and Merrill (2001) have demonstrated in relation to adult access, fortunes in terms of 'getting' in are likely to vary considerably from Spain to Sweden, from ancient universities to those established after the breaking of binary lines and from the social sciences to 'high status knowledge areas'. 'Getting on' and 'getting beyond' are another matter, and even if some aspects of access are 'solved', attention now must be turned to questions of retention and progression if the gains of access are to be consolidated.

\section{NOTES}

1. The terms élite, mass and universal refer to the delineations made by M. Trow (1973).

2. According to OECD (2001a) definitions, higher tertiary level A education requires a minimum cumulative theoretical duration of 3 years' full-time equivalent study and normally are 4 years equivalent in duration. They are not exclusively delivered at universities, and conversely it is not only type A programmes that universities offer. Type B programmes focus on practical, technical and occupational skills leading to direct entry to the labour market, though they may contain some theoretical components, and are of a minimum of 2 years equivalent in duration.

3. Scott (1995, p. 35) suggests that HE systems can be classified as dual, binary, unified and stratified. Both dual and binary systems contain alternative forms of HEI; in the case of the latter, alternative institutions have been set up to complement and rival existing traditional structures. In unified systems, there is no formal differentiation of institutions and in stratified systems institutions are allocated a role within a total system.

4. There are some exceptions. In addition, there are 35 Berufsakademien, which are either publicly or privately maintained, and also comprehensive universities (Gesamthochschulen) in a limited number of federal states which provide the same courses of study as universities, but also courses as provided by Fachhochschulen and so-called integrated courses with graduated qualifications after three or four years. 
5. See for instance the recent UNESCO-CEPES report on Bulgaria (Georgieva et al., 2002). In this issue, P. Davies considers the implications of the Bologna agreement more fully.

6. McGivney (1993, pp. 26-30) describes in summary a range of theories of participation, using the following classifications: Needs Hierarchy Theory; Congruence; Force-Field Theory; Life Transitions Theory; Reference Group Theory; and Social Participation. She refers also to certain 'Composite Theories' which have a number of common features: Chain of Response Model; Recruitment Paradigm; Psychosocial Interaction Model; Combination of Favorable Circumstances. See also Davies et al. (2002) for an overview of how different factors impact on individual adults' decision-making processes. Davies (1999) provides an overview of institutional factors, and Courtney (1990) of psychological models.

7. The means-tested maintenance grant in Ireland, for instance, ranged from $€ 902-€ 2254$ in 2001 and has been criticised by many as being inadequate (Thornhill, 2001, p. 53). In Spain, fees of between $€ 400$ and $€ 650$ were payable in 2001, with the added incentive that these would increase if courses were repeated (San Segundo, 2002). Scott (2002, pp. 148-149) and others have noted that the chronic shortage of funding in many public universities in Central and Eastern Europe means they rely on fee income so that, in effect, they are often semi-privatised. Private institutions often have a comparative advantage because of the lack of dynamism and flexibility of the public structure, though Scott is not clear as to whether these advantages will be sustained as the state institutions become better resourced. Even with Poland's enthusiasm to develop the private sector, a loan system with preferential treatment for students (albeit those under 25) from low-income families exists (Wiercińska \& Piotrowski, 2003).

8. My emphasis is based on the fact that, although in the UK these courses are given a credit rating, there is little evidence that the credit so achieved is transferable to the traditional undergraduate qualification, the first degree.

9. For the Dutch, these are ICT competences, citizenship and social skills such as learning to learn, problem solving and working in teams. This perspective is frequently taken in national discussions and is evident in many national responses to the Memorandum on Lifelong Learning (CEDEFOP, 2001, p. 10-11), though, here, the importance of not downgrading traditional basic skills is also emphasised in the context of 'continuing functional illiteracy'.

\section{REFERENCES}

Albert, C. (2000) Higher education demand in Spain. The influence of labour market signals and family background, Higher Education, 40, pp. 147-162.

BERMINGHAM, M. (2002) The spider - a multi-dimensional model from Ireland, in: M. WOODROW (Ed) Pyramids or Spiders? Cross-sector Collaboration to Widen Participation: Learning from International Experience (Edinburgh, Scottish Funding Councils).

BonHAM, B. S. (2002) Educational mobility in the U.S. through the Community College transfer function, in: M. J. OsBoRNE, J. GALlACHER \& M. MURPHY (Eds) A Research Review of FE/HE Links - A Report to the Scottish Executive 
Enterprise and Lifelong Learning Department (Stirling/Glasgow, Centre for Research in Lifelong Learning).

Bourgeois, E., Duke, C., LuC-Guyot, J. \& Merill, B. (1999) The Adult University (Buckingham, SRHE/OU).

Bourgeois, E. \& Frenay, M. (2001) University Adult Access Policies and Practices across the European Union; and their Consequences for the Participation of Nontraditional Adults. Final Report to European Commission of TSER Project, SOE2-CT97-2021.

Bourgeois, E. \& MERILL, B. (2001) Learning in universities: impacting on private and public lives, in: Proceedings of ESREA 2001 Wider Benefits of Learning, Lisbon, 13-16 September 2001.

Brennan, J. \& LitTle, B. (1996) A Review of Work-based Learning in Higher Education (Sheffield, DfEE).

BRON, A. \& AGÉLII, K. (2000) Non-traditional students in higher education in Sweden: from recurrent education to lifelong learning, in: H. SCHUETZE \& M. SLOWEY (Eds) Higher Education and Lifelong Learners (London, Routledge/ Falmer).

BuRTCH, B. (2002) Review of Further Education/Higher Education Links in Canada, in: M. J. Osborne, J. Gallacher \& M. MurPhy (Eds) $A$ Research Review of FE/HE Links - A Report to the Scottish Executive Enterprise and Lifelong Learning Department (Stirling/Glasgow, Centre for Research in Lifelong Learning).

CASES, M. R. \& LopeZ, R. M. (1996) Las escuelas de padres: apoyo al desarrollo, in: A. SÁNCHEZ (Ed) Relación Familia-Escuela en el Proceso Educativo de Niños y Adolescentes (Granada, Osuna).

CEDEFOP (2001a) Technology Will Improve Access to Learning for People with Disabilities. http://www2.trainingvillage.gr/etv/elearning/surveys/surmain. asp

CEDEFOP (2001b) Summary and Analysis of the Feedback from Member States and EEA Countries as part of the Consultation on the Commission's Memorandum on Lifelong Learning (Thessaloniki, CEDEFOP).

CERYCH, L. (2002) Higher education reform in the Czech Republic: a personal testimony regarding the impact of foreign advisers, Higher Education in Europe, XXVII, pp. 111-121.

COUNCIL OF EUROPE (1996) Project on Access to Higher Education in Europe: working report. Part 1 Synthesis and Recommendations (Strasbourg, Council of Europe).

COUNCIL OF EUROPE (1999) Lifelong Learning for Equity and Social Cohesion: a new challenge to higher education. Working on meeting the needs of all students in a changing society. Bornholm, 27-29 May 1999 (Strasbourg, Council of Europe).

CoUnCIL OF EUROPE (2001) Lifelong Learning for Equity and Social Cohesion: a new challenge to higher education. Final Conference, Paris, 15-17 November 2001 (Strasbourg, Council of Europe).

DAvies, P. (1995) Adults in Higher Education: International Perspectives on Access and Participation (London, Jessica Kingsley).

DAVIES, P. (1996) Noise rather than numbers: access to higher education in three European countries, Comparative Education, 32, pp. 111-123.

DAVIES, P. (1999). Rights and rites of passage: crossing boundaries in France, International Fournal of Lifelong Education, 19, pp. 215-224. 
Davies, P., Osborne, M. \& Williams, J. (2002) For Me or Not for Me - Mature Student Participation in HE (London, DfES, Research Report 297).

DEPARTMENT OF EDUCATION AND SCIENCE (1991) Higher Education - A New Framework, Cm. 1541 (London, HMSO).

Dijkstra, F. (2001) Netherlands, in: COUNCIL OF EUROPE Lifelong Learning for Equity and Social Cohesion. A New Challenge for Higher Education, pp. 95-100, Final Conference, Paris, 15-17 November 2001.

EGGINK, B. (2002) The bridge - spanning the sectors in the Netherlands, in: $M$. WoODRow (Ed) Pyramids or Spiders? Cross-sector Collaboration to Widen Participation: Learning from International Experience (Edinburgh, Scottish Funding Councils).

EUROPEAN COMMISSION (1995) White Paper - Teaching and Learning: Towards the Learning Society (Brussels, EC).

EUROPEAN COMMISSION (2001a) The Memorandum on Lifelong Learning (Brussels, EC).

EURopean COMMISSION (2001b) Making a European Area of Lifelong Learning a Reality. COM (2001) 678 (Brussels, EC).

FEUTRIE, M. (1996) Towards a learning society? The French experience, The European Fournal of Continuing Education (http://zeus.slais.ucl.ac.uk/vrc).

Gallacher, J., Osborne, M., \& Postle, G. (1996) Increasing and widening access to higher education: a comparative study of policy and provision in Scotland and Australia, International fournal of Lifelong Education, 15, pp. $418-437$.

GELlERT, C. (Ed) (1993) Higher Education in Europe (London, Jessica Kingsley).

Georgieva, P., with Todorova, L. \& Pilev, D. (2002) Higher Education in Bulgaria (Bucharest, UNESCO-CEPES, UNESCO-CEPES Monograph Series).

HALSEY, A. H. (1992) An international comparison of access to higher education, in: D. PHILIPS (Ed) Lessons of Cross National Comparisons in Education, Oxford Studies in Comparative Education, Vol. 1 (Wallingford, Triangle Books).

Inglis, T. \& MurPhy, M. (1999) No Room for Adults? A Study of Mature Students in University College Dublin. Report prepared for the Higher Education Authority (Dublin, Social Science Research Centre/Adult Education Office, University College Dublin).

INTERNATIONAL LABOUR OFFICE (2000) Lifelong Learning in the Twenty-First Century: The Changing Roles of Educational Personnel. Report for discussion at the Joint Meeting on Lifelong Learning in the Twenty-first Century: The Changing Roles of Educational Personnel, Geneva, 10-14 April 2000.

JALLADE, J.-P. (2000) Lifelong learning in French universities: the state of the art, European Fournal of Education, 35, pp. 301-315.

JENSEN, H.-P. \& HAUCH, A. (2003) University continuing education in Denmark, in: M. Osborne \& E. ThomAs (Eds) Lifelong Learning in a Changing Continent: Continuing Education in the Universities of Europe (Leicester, NIACE).

Jouve, M. (2001) Making a European Area of Lifelong Learning a reality, in: COUNCIL OF EUROPE Proceedings of Lifelong Learning for Equity and Social Cohesion: a new challenge to higher education. Final Conference Paris, 15-17 November 2001 (Strasbourg, Council of Europe).

MARGA, A. (2002) Reform of education in Romania in the 1990s: a retrospective, Higher Education in Europe, XXVII, pp. 123-135. 
MINISTRY OF EDUCATION AND SCIENCE (2001) The Debate on the Commission's Memorandum on Lifelong Learning 2001. The Work Group for Lifelong Learning 2001-06-12 (Stockholm, Ministry of Education and Science).

MoE, F. (2003) University continuing education in Norway, in: M. OsBoRNE \& E. Thomas (Eds) Lifelong Learning in a Changing Continent: Continuing Education in the Universities of Europe (Leicester, NIACE).

MORGAN-KLEIN, B. (2000) Researching Inclusion in Higher Education: a review of policy and debate in post-devolution Scotland. Paper presented at SCUTREA, $30^{\text {th }}$ Annual Conference, 3-5 July 2000, University of Nottingham.

MorgAN-KLEIN, B. \& MURPHY, M. (2001) Access and recruitment: institutional policy in widening participation, in: P. TROWLER (Ed) Higher Education Policy and Institutional Change (Buckingham, SRHE and Open University Press).

Murphy, M., Morgan-Klein, B., Osborne, M. \& Gallacher, J. (2002) Widening Participation in Higher Education: Report to Scottish Executive (Stirling, Centre for Research in Lifelong Learning/Scottish Executive).

NAIDOO, R. (2000) The 'Third Way' to widening participation and maintaining quality in higher education: lessons from the United Kingdom, Fournal of Educational Enquiry, 1, pp. 24-38.

Nurmi, J. (1998) Tracks to Whom? Selection into Expanding Higher Education. Report 43. Research Unit for the Sociology of Education (RUSE).

OECD (2001a) Education at a Glance (Paris, OECD).

OECD (2001b) Economics and Finance of Lifelong Learning (Paris, OECD).

Osborne, M. (1995) Spain, in: P. DAVIES (Ed) Adults in Higher Education - International Perspectives in Access and Participation (London, Jessica Kingsley).

Osborne, M. (2003) Policy and practice in widening participation - a six country comparative study of access as flexibility, International fournal of Lifelong Education, 22, pp. 43-58.

ORTEGA, J. \& CAMARA, E. (2001) Entry to university for adults over 25 years of age in Spain: Study of the Current situation carried out by teachers and students of State Centres of Adult Education, in: Proceedings of Researching Widening Access: International Perspectives (Glasgow, Centre for Research in Lifelong Learning).

Petrongolo, B. \& SAn Segundo, M. (2002) Staying-on at school at sixteen. The impact of labour market conditions in Spain, Economics of Education Review, 21, pp. 353-365.

Powis, D. A. \& BRISTOw, T. (1997) Top marks don't necessarily make top medical students, Medical Fournal of Australia, letters, 166, pp. 613.

Rolfe, I. E. \& Powis, D. A. (1997) Selecting Australian doctors of the future, Medical Fournal of Australia, 166, pp. 229-230.

RugaAs, B. (2001) Opening Address, in: COUNCIL OF EUROPE Proceedings of Lifelong Learning for Equity and Social Cohesion: a new challenge to higher education. Final Conference Paris, 15-17 November 2001 (Strasbourg, Council of Europe).

SANGRA, A. (2001) The consolidation of a Virtual University, Lifelong Learning in Europe, VI, pp. 76-84.

SAn Segundo, M. \& Valiente, A. (2002) Widening access in Spain: the unexpected effects of two policy changes, fournal of Adult and Continuing Education, 8, pp. 46-59. 
Schuetze, H. \& Slowey, M. (2000) (Eds) Higher Education and Lifelong Learners - International Perspectives on Change (London, Routledge/ Falmer).

ScotT, P. (1995) The Meanings of Mass Higher Education (Buckingham, SRHE/OUP).

ScotT, P. (2002) Reflections on the reform of higher education in Central and Eastern Europe, Higher Education in Europe, XXVII, pp. 137-152.

SCOTTISH OFFICE (1998) Higher Still - new courses and qualifications in Scotland from August 1999. http://www.scotland.gov.uk/library/documents-w2/ hsl-00.htm

SCOTTISH PARLIAMENT (2002) Interim Report on the Lifelong Learning Inquiry (Edinburgh, Scottish Parliament).

SLOWEY, M. (2000) The United Kingdom: redefining the non-traditional student: equity and lifelong learning in British higher education, 1985-2000, in: H. SCHUETZE \& M. SLOWEY (Eds) Higher Education and Lifelong Learners International Perspectives on Change (London, Routledge/Falmer).

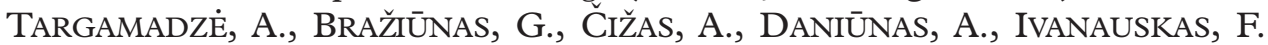
et al. (2000) Universitetiniu ir neuniversitetiniu studiju plètotés koncepcijos metmenys [An Outline of the Concept of University and Non-university Study Development] (Vilnius, Lietuvos mokslo taryba).

TOYNe, P. (1990) Achieving wider access, in: G. PARRY \& B. WAKE (Eds) Access and Alternative Futures for Higher Education (London, Hodder and Stoughton).

Trow, M. (1973) Problems in the Transition from Elite to Mass Higher Education (Berkeley, Carnegie Commission for Education).

TROw, M. (1999) From mass higher education to universal access: the American advantage, Minerva, 37, pp. 303-328.

THOmAs, L. (2002) Collaboration with and between HEIs in England: a review of policy and practice, in: L. THOMAS, M. COOPER \& J. QUINN (Eds) Collaboration to Widen Participation in Higher Education (Stoke-on-Trent, Trentham Books).

THORNHILL, D. (2002) Widening access to higher education in Ireland, in: L. Thomas, M. CoOper \& J. QUINN (Eds) Collaboration to Widen Participation in Higher Education (Stoke-on-Trent, Trentham Books).

UNESCO (1998a) Mumbai Statement on Lifelong Learning, Citizenship and the Reform of Higher Education (http://www.unesco.org/education/uie/online/olpub. html).

UNESCO (1998b) Higher Education in the 21 ${ }^{\text {st }}$ Century: vision and action. Final Report of the World Conference on Higher Education, Paris, 5-9 October 1998 (Paris, UNESCO).

UNIVERSITIES SCOTLAND (2001) Access to Achievement: a guide to how the Scottish higher education sector is promoting social exclusion (Edinburgh, Universities Scotland).

WHEELAHAN, L. (2002) Links between vocational education and training and higher education in Australia, in: M. J. OsBoRne, J. GAllacher \& M. MURPHY (Eds) A Research Review of FE/HE Links - A Report to the Scottish Executive Enterprise and Lifelong Learning Department (Stirling/Glasgow, Centre for Research in Lifelong Learning).

Williams, J. (Ed) (1997) Negotiating Access to Higher Education - the discourse of selectivity and equity (Buckingham, SRHE/OUP). 
Woodrow, M. (2002) Pyramids or Spiders? Cross-sector Collaboration to Widen Participation: Learning from International Experience (Edinburgh, Scottish Funding Councils).

Woodrow, M. \& Thomas, E. (2002) Pyramids or Spiders? Cross-sector Collaboration to Widen Participation: Learning from International Experience A comparative study to identify the most effective ways for post compulsory institutions to work together to widen participation, in: L. THOMAS, M. COOPER \& J. QUINN (Eds) Collaboration to Widen Participation in Higher Education (Stoke-on-Trent, Trentham Books).

WolTER, A. (2000) Germany: non-traditional students in German higher education: situation, profiles, policies and perspectives, in: H. SCHUETZE \& M. SLOWEY (Eds) Higher Education and Lifelong Learners - International Perspectives on Change (London, Routledge/Falmer). 